\title{
Women's role and support for the closed fishing season in the small-scale fisheries (SSF) of Davao Gulf, Philippines
}

Edison D Macusi ( $\nabla$ edmacusi@gmail.com )

Davao Oriental State University https://orcid.org/0000-0002-9714-1074

\section{Erna S. Macusi}

Davao Oriental State University

Charlen Mae Gaab

Davao Oriental State University

\section{Anna Barboza}

Ghent University: Universiteit Gent

\section{Larry N. Digal}

School of Management, University of the Philippines Mindanao (UPmin)

\section{Research Article}

Keywords: Closed-fishing season, Davao Gulf, Gender, Small-scale fisheries (SSF), women empowerment

Posted Date: August 10th, 2021

DOl: https://doi.org/10.21203/rs.3.rs-638646/v1

License: (c) (1) This work is licensed under a Creative Commons Attribution 4.0 International License. Read Full License 


\section{Abstract}

Women's role and support for the fisheries are barely acknowledged, they are stereotyped and marginalized and given limited participation in the fisheries. This study aims to describe the role of women and investigate their support for the closed fishing season in the small-scale fisheries (SSF) of Davao Gulf, Philippines. Survey data were collected in six study sites, only surveying women respondents involved in fishing and fishery-related activities. Interviews were conducted from November 2019 to July 2020 with respondents from Governor Generoso, Lupon, Davao City, Sta. Maria, Malita, and Don Marcelino $(\mathrm{N}=255)$. The information collected was validated through seven focus groups with a total number of participants, $N=112$. Results showed that women respondents who live near the shore, were poorly educated, attended elementary level (38\%), do not own any parcel of land (91\%), but have access to microfinance credit (64\%). Women participated in the fisheries by gleaning for food and income. Some of their activities were performed to support their husbands, including preparing fishing gears (23\%), food processing $(6 \%)$, collecting and sorting fishery products $(10 \%)$, marketing fish catches $(25 \%)$, and gleaning (21\%). Other results showed that women strongly support the closed fishing season which was significantly influenced by fisheries-related variables e.g. proportion of catch sold, and belonging to a family of fishers $[B=0.459$ (S.E. $=0.188$ ), Wald $=5.928 d f=1, p=.015]$. They support the policy for sustainability of their husband's catches and their livelihood. Women also mentioned the need for financial seed capital for fishing gears, fishing operation and rented stalls for selling of fish.

\subsection{Introduction}

In developing countries, women living in coastal areas support the small-scale fisheries (SSF) by participating as gleaners, fishers, traders, fish farmers, and fish processors (Arenas and Lentisco, 2011; Weeratunge et al., 2010). This was also similarly documented in the agriculture and the fisheries sectors where men regularly considered women as labor assistants rather than co-workers, and co-equal (Ingabire et al., 2018). However, women do fish and participate in a range of other fishery-related activities that contribute significantly to household food security, income, and sustainable fisheries (Fitriana and Stacey, 2012; Kim and Choi, 2020). These activities are in addition to ensuring the well-being of their children and families (Dolan, 2001; Parks et al., 2014). Yet, women are still looked down in the fisheries as merely labor providers (Siason, 2001). They are usually identified as fishers' wives, and their works are considered as second rate domestic labor in caring for their families, bearing children, collecting water and firewood, preparing food, and cleaning the house (Mutia et al., 2020).

At present, the literature on women's roles in the fisheries is remarkably bereft of information regarding their roles on conservation in the small-scale fisheries; they are still marginalized, stereotyped, and undervalued (Bennett, 2005). Customarily, fishing is considered a masculine activity, and women's roles are found to be of the more supportive type (Cliffe and Akinrotimi, 2015; Lentisco and Lee, 2015). In reality, women actually constitute a high proportion of workers in subsistence fisheries, aquaculture, artisanal and industrial processing, fishery equipment maintenance, and the trading and retail of fresh fish (Ferrer et al., 2014; Pavo and Digal, 2017). Almost 47\% of the 120 million fisherfolk who earn their 
money from fishing and fishery product processing are women who also work in the local markets, in coastal communities, and even among their neighborhoods (Biswas, 2017). There is a traditional view that the only contribution of women to fisheries are limited to postharvest and marketing (Ferrer et al., 2014), but recent studies (Mutia et al., 2020) oppose this view as women do make contributions in the pre-fishing, post-fishing, and aquaculture activities; they were highly engaged and productive in the fisheries. One set-back that keeps us less informed about their roles and therefore how we can mitigate this problem is the lack of documentation on their participation with regards to fisheries resources management and policy decision-making (Lentisco and Lee, 2015). Because fishers and their wives differ in their knowledge of marine resources and how they attach value to natural resources, this implies differences in their resource use and exploitation, also implying varying participation in local policy and decision-making (Lentisco and Lee, 2014; Siar, 2003). Since there is little documentation about women's participation with the management process of the fisheries, policy, and decision-making, they are seldom given management roles even in various community-based programs (Bradford and Katikiro, 2019; Katikiro et al., 2015). With the implementation of the closed fishing season in Davao Gulf, there was minimal information on how women may have supported their husbands given this policy that was suddenly implemented in 2014 (Macusi et al., 2021; Rola et al., 2018). Since there is a gendered difference on how men and women value their natural resources and ecosystem services (Fortnam et al., 2019), a better understanding on how women supported their husbands could provide fisheries managers on appropriate programs that could help in fisheries conservation. Studies on their roles and contribution in the fisheries should represent a constant area of study. Their participation should be brought to the forefront as these roles change over time depending on local context (Lentisco and Alonso, 2012). This study aimed to identify the various roles that women played in the small-scale fisheries in Davao Gulf and determined the influencing factors related to their support for the implementation of the closed fishing season policy in Davao Gulf. It adds contribution to the gender literature in terms of women's participation in fisheries, documented their access to resources and what support they extended to their husbands to realize the goals of the closed fishing season.

\subsection{Materials And Methods}

\section{A. Description of study area}

The Davao Gulf is situated in the southeastern portion of Mindanao, Philippines with an area of 308,000 hectares (Villanueva, 2018). The selected study sites are as follows: 1) Bunawan, and Lasang from Davao City, which have populations of 23,495 and 10,223 inhabitants according to a 2015 census. The city exports banana, coconut, papaya, durian, mangosteen, and cacao as well as processed fish food products (PhilAtlas, 2020); 2) Governor Generoso in Davao Oriental is a coastal municipality with a population of 55,109 (PhilAtlas, 2020), the livelihood are mainly agricultural and fishing with a number of ringnet based fishing companies and small-scale fishers found in the area (Macusi et al., 2016; Villanueva, 2018); 3) Lupon, Davao Oriental has a population of 65,785 with livelihood mainly based on agriculture and fishing. A number of the fishers are actively engaged in fishing for tuna handlines, hook and lines, multiple hooks and lines, longlines, squid jiggers, and ringnet fishers (Macusi, 2015); 4) Sta. 
Maria, 5) Malita, and 6) Don Marcelino, Davao Occidental are study sites with livelihood primarily dependent on coconut, banana farming, livestock raising, and fishing with a population ranging from 44,554 to 117,746 . All study sites were chosen based on road access to the area, permission allowed by the barangay or the local government unit, the number of fishers, and therefore a more representative fishing population and known engagement of women in the fisheries based on scoping interviews with the barangay chairmen and other previously interviewed fishers.

\section{B. Data collection}

Field sampling was conducted from November 2019 to July 2020 in the selected study sites within the Davao Gulf region. Data collection sites were chosen based on the number of fishers present in the fishing villages specifically ones with a high proportion of women participating in the fisheries (verified prior to the data collection). The surveys were conducted in the respondents' homes, fish landing areas, and even in barangay halls. A purposive sampling design with a minimum of 30 respondents from each study site was adopted ( $N=255$ respondents). The minimum number for sample size used was $n=30$ for the interviews which was a number that provides a degree of saturation on the responses of the participants as applied in previous studies (Dworkin, 2012; Macusi et al., 2021; Macusi et al., 2020; Mason, 2010).

\section{Interview survey}

The survey used a semi-structured questionnaire that included both close-ended and open-ended questions, which resulted in both quantitative and qualitative and data. The questions varied in topics from fishing characteristics, involvement in community decision-making and leadership, respondent participation in fisheries capture and production, calendar of fishing and domestic activities, pre- and postharvest work, participation in resource management, and access to technology or financial credit. Prior to the data collection, pilot interviews were conducted to ensure that the survey's questions accurately determined the study's aims. During the pilot interviews, ten women from the study sites in Governor Generoso and Sta. Maria were chosen and interviewed. The results from the ten respondents were not included in the study's sample size or data analysis; each questionnaire approximately took 15 to 25 minutes to complete.

\section{Focus Group Discussion (FGD)}

A focus group discussion was also included in this study to provide a validation of the information gathered from the semi-structured questionnaire. Focus groups provide contextualization of information taken from the results of the semi-structured interviews and expert opinions regarding the fishing sectors as well as their support for the closed fishing season. Focus groups were mainly composed of a minimum of 12 participants per study site. Governor Generoso, Lupon, and Bunawan all had 12 participants, Lasang had 14 while Malita 13, Don Marcelino 16, and Sta. Maria had 33 participants. There was a total of seven focus groups held and a total of $\mathrm{N}=112$ participants. The focus groups were facilitated by a knowledgeable moderator from the research group and aided by documenters who 
recorded the discussions and photographed the activities. Questions asked were primarily open-ended and focused on the women's household activities, community issues, and their suggested solutions, and their involvement in the fishing industry and community. The discussions roughly lasted for 30 minutes to 1 hour.

\section{Data Analysis}

Primary data derived from the interview were first encoded using Microsoft Office Excel 2016, and then different data variables were visualized in the various study sites. Their descriptive statistics were taken, including frequency counts and percentages, which were tabulated, and then interpreted. Whenever possible, all numbers with decimal places were rounded to the nearest whole number because individual respondents were surveyed. Three data categories were first explored considering the contribution of women to the fisheries mainly: sociodemographic, fisheries-related activities, and access-related information. Under the data category "sociodemographic" are the following: age, years in the community, household size, land ownership, distance to shore, education, and then under the data category "fisheries activities" are boat ownership, fish hold capacity, family of fisher, proportion fish sold and then under "access" we have: access to credit, extension, membership and awareness/information. All the variables under each data category were reduced to one factor through PCA (principal components analysis). The factor scores were later used for binary logistic regression to analyze whether the women supported the implementation of the closed fishing season. The three variables which used the regression scores derived from the PCA were considered as independent predictors for the binary logistic regression. The equation was checked, and then the data were fitted to produce the graphs for further understanding the relationship of the three variables. The results were then interpreted together with the qualitative data and then related to existing roles of women in the fisheries based on existing frameworks like the studies of Siar (2003) and Siason (2001).

\subsection{Results}

\subsection{Sociodemographic profile}

Results showed that the average age of respondents was 41 years old, the youngest respondent was 17, and the oldest was 72 years old. Women in the age range of 21 to 30 years old were actively engaged in the fisheries sector, with $27 \%$ more participants than in the adult age range of 41 to 50 years old (only $26 \%$ were actively engaged). This active engagement decreased to $7 \%$ in ages above 60 years old (see Fig. 2A). For the number of years spent in the community, the respondents ranged from 21 to 30 years in all the study sites with the following percentages of respondents from each village surveyed in this range: $39 \%$ from Sta. Maria, 36\% from Malita, 28\% from Governor Generoso, 24\% from Davao City, and 22\% for Lupon and Don Marcelino. Most of the respondents have been living in their areas, their entire lives (Fig. 2B). In terms of household size, most of the women in Sta. Maria (86\%), Governor Generoso (73\%), Malita (72\%), Don Marcelino (71\%), Lupon (63\%), and Davao City (55\%) have a household size that ranged from 1 to 5 individuals (Fig. 2C). The location of the respondents' houses from the shoreline did 
not vary extensively from each study site. This means, most of the women and their families live close to the shore and do not own any strip of land for farming or even for a decent housing. In Davao City, $100 \%$ of respondents were located within a 0-5 km distance from the shoreline. In Lupon and Governor Generoso, $86 \%$ and $70 \%$ of respondents are also living from 0 to $5 \mathrm{~km}$ from the shoreline. In Don Marcelino, a little more than half, $54 \%$ of the respondents were living near the shoreline and in Sta Maria, only $38 \%$ of respondents lived near $0-5 \mathrm{~km}$ from the shoreline (Fig. 2D). The majority of fishers, 86 to $98 \%$ of all respondents do not own their land. The lack of hard assets such as a good house and land ownership makes these fishing families vulnerable to poverty (Fig. 2E). Women from the study sites were found to have low educational attainment, with most of them having reached only a primary level of education. Those who were able to complete their primary level of education were $47 \%$ in Davao City, $41 \%$ in both Governor Generoso and Don Marcelino, 38\% in Malita, 32\% in Sta. Maria and 26\% in Lupon. A lower percentage of respondents reported having finished their secondary level education with $32 \%$ in Don Marcelino, 26\% in Lupon, 24\% in Governor Generoso, 19\% in Davao City, 17\% in Malita, and 16\% in

Sta. Maria. Among all respondents surveyed, only $3 \%$ self-reported having finished their college degrees in all the study sites they were from (Fig. 2F).

\subsection{Engagement in the Fisheries}

Most of the respondents belong to a family of fishers, $87 \%(\mathrm{~N}=223)$. About $95 \%$ of the respondents in Sta. Maria, followed by $94 \%$ in both Governor Generoso and Lupon, $88 \%$ in Don Marcelino, $79 \%$ in Malita, and $66 \%$ in Davao City belong to a fishing family (Fig. 3A). Moreover, the respondents were actively engaged in the fisheries, including their husbands (44\%), fathers (24\%), mother (12\%) and their son/s (12\%), brother (4\%) and sister (4\%) (see Fig. 3B).

\section{Boat ownership and fish hold capacity}

The respondents from Don Marcelino mentioned that their families owned their fishing boats (85\%). In comparison, $70 \%$ of the respondents from Lupon mentioned owning their boats, and $62 \%$ of respondents in Malita, and $60 \%$ in Governor Generoso reported owning their boats. In contrast, about $30 \%$ and $24 \%$ of respondents from Davao City and Sta. Maria reported their ownership of boats (Fig. 4C). The fish holding capacity of the boats $(\mathrm{kg})$ ranged from $0-100 \mathrm{~kg}(35 \%), 101-300 \mathrm{~kg}(61 \%), 301-400 \mathrm{~kg}(1 \%), 401-500 \mathrm{~kg}$ $(3 \%)$, and $>501 \mathrm{kgs}(0 \%)$ of fish in all the study sites. In terms of capacity with the highest percentages within a given range, the fish hold capacity of $101-300 \mathrm{~kg}$ range has $84 \%$ for Sta. Maria, $77 \%$ for Davao City, $51 \%$ for both Governor Generoso and Don Marcelino, $52 \%$ for Malita, and 47\% for Lupon (Fig. 4D).

\section{The proportion of catch sold}

Overall, $63 \%$ of the respondents have mentioned selling all their catch, $32 \%$ for selling more than half of their catch that day, and only $5 \%$ have mentioned that they will sell less than half of their catch. For instance, in the majority of the fishers in Davao City will sell more than half of their catch (52\%), while in Don Marcelino and Lupon 85\% have mentioned selling all their catch. In Governor Generoso and Malita $64 \%$ have mentioned selling all their catch, and almost half of respondents in Sta. Maria has mentioned 
selling all their catch, revealing their preference for cash which they can use to purchase their other needs (see Fig. 4E).

\section{Common species caught}

Species reportedly caught include bigeye scad (Selar crumenophthalmus) in Don Marcelino (41\%), Davao City (42\%), Malita (39\%), Sta. Maria (37\%), Governor Generoso (35\%), and Lupon (29\%). Frigate tuna (Auxis thazard) in Governor Generoso (40\%), Don Marcelino (35\%), Malita (24\%), Lupon (23\%) Sta. Maria (22\%), and Davao City (13\%). This was followed by roundscad (Decapterus macrosoma) in Sta. Maria (35\%), Governor Generoso (15\%), Davao City (13\%), Malita (12\%), Don Marcelino (10\%), and Lupon (8\%). Other species mentioned include Indian mackerel (Rastrelliger kanagurta) in Malita (14\%), Davao City (10\%), Lupon (8\%), in Governor Generoso (5\%), in Sta. Maria (3\%), and in Don Marcelino (2\%). Bicolor goatfish (Parupeneus barberinoides) in Lupon (12\%), Davao City (6\%), Governor Generoso (5\%), Malita (3\%), Don Marcelino (1\%) is less often found.In Lupon (9\%), Davao City (6\%), Malita (5\%), Don Marcelino (4\%) Bali sardinella (Sardinella lemuru) is also not as commonly caught. Women also mentioned Indian threadfish (Alectis indica) in Davao City (10\%), Lupon (4\%), Malita (3\%), Don Marcelino (1\%); striped ponyfish (Aurigequula fasciata) in Lupon (4\%), Davao City (3\%), Don Marcelino (2\%), and Sta. Maria (1\%); roundscad (Decapterus macrosoma) in Davao City (13\%), Lupon and Sta. Maria (1\% each) and skipjack tuna (Katsuwonus pelamis) in Davao City and Lupon (3\%), in Don Marcelino (2\%), and Sta. Maria (1\%) (Fig. 4F).

\subsection{Access to various community services}

\section{Access to credit}

The majority of the respondents have access to financial credit, with $83 \%$ of women in Malita, $68 \%$ in Don Marcelino, 65\% in Lupon, 64\% in Sta. Maria, 60\% in Davao City, and 45\% in Governor Generoso having this access (Fig. 4A). Financial credit access was $100 \%$ in the form of cash in Lupon, $91 \%$ in Davao City, 79\% in Governor Generoso, and 55\% in both Malita and Don Marcelino, and only 28\% in Sta. Maria; other forms of credit access are material kinds found in Sta. Maria (50\%), in Don Marcelino (45\%), in Malita (40\%), in Governor Generoso (21\%), and in Davao City (9\%). While both cash and "in-kind" were available to respondents in Sta. Maria (20\%) and in Malita (5\%) (see Fig. 4B). They usually spend the money borrowed to buy fishing equipment (52\%), food for their household (20\%), other domestic expenses (14\%) e.g., house repair, children's education, and medical bills of the respondents.

\section{Access to extension services}

Extension services are defined as technical knowledge (e.g., seminars on financial matters, credit access, training on new methods of production) and material donations provided by the government and nongovernment organizations to farmers and fishers. Technical assistance and capacity building can either be received well or poorly depending on how the community and beneficiaries view intervention. The majority of respondents from the study sites of Lupon (62\%), Don Marcelino (62\%), and Malita (54\%) 
have access to extension services (Fig. 4C). These were both in-kind or material donations from fishing boats to fishing gear and technical seminars on fishing, health, or livelihoods.

\section{Membership to a community organization}

Membership to community organizations is one way for the government or other NGOs to provide fishing communities with technical assistance or support when they cannot give it to individuals directly. When respondents were asked about their membership to fishing cooperatives, sadly, the majority of them were not members of any fishing organization, with $90 \%$ in Governor Generoso and Malita, $86 \%$ in Sta. Maria, $73 \%$ in Davao City, and 63\% in both Lupon and Don Marcelino (Fig. 4D).

\section{Access to information, e.g., awareness on open and closed fishing season}

Seventy-eight percent of respondents agree on the open and closed fishing season policy. Among all respondents, there were $92 \%$ in Sta. Maria, $82 \%$ in Lupon and $62 \%$ in Governor Generoso who were aware of the implementation of the open and closed fishing season while in Davao City and Don Marcelino 68\%, and Malita $66 \%$ of the respondents were not aware (Fig. 4E).

\section{Support for the implementation of the closed fishing season policy}

Women were asked if they support the implementation of the closed fishing season policy and a majority of them approved the policy (78\%). Some of the respondents have mentioned that as a citizen they ought to follow the law for the reason that "fish will lay their eggs during the Habagat months from June to October. The other respondents $(22 \%)$ who said no to the implementation of the closed fishing season mentioned that they have no other source of income apart from fishing (Fig. 4F).

Results of the principal component analysis (PCA) for variable reduction where the different variables were reduced to find how they may influence the decision of women to support the closed fishing season show that in the fisheries-related variables, the variables, proportion of catch sold (0.639), boat ownership (0.488) and belonging to a family of fisher (0.428) have high positive loadings. In addition, for the variables related to access, credit access $(0.652)$, and membership to community organizations $(0.599)$, they also contribute highly and positively, but for the factor loadings of the sociodemographic variables of age $(-0.647)$ and a number of years in the community $(-0.614)$, they contribute highly but on the opposite direction (negative). The factor scores from the PCA analyses were then used for the subsequent binary logistic regression analysis.

The result of the logistic regression on whether women support the conservation policy of closed fishing season or not show that it was significantly influenced by fisheries related variales for instance, proportion of catch sold, boat ownership, boat fish hold capacity and belonging to a family of fishers. For the aspect of access to services which includes financial services, extension services, awareness, and membership to community organizations, this was not significant $[B=-0.025$ (S.E. $=0.183$ ), Wald $=0.19 \mathrm{df}$ $=1, P=.890]$. However, for the fisheries factors, this was significant $[\mathrm{B}=0.459$ (S.E. $=0.188)$, Wald $=5.928$ $\mathrm{df}=1, p=.015]$ mainly by the proportion of catch sold and belonging to a fisher family. The constant term 
was also highly significant $[B=1.330($ S.E. $=0.216)$, Wald $=37.85 \mathrm{df}=1, p=.0001]$. However, there was no significant influence of the variables from the sociodemographic factors with regards to influencing women respondents in terms of their support for the closed fishing season $[B=0.036$ (S.E. $=0.158)$, Wald $=0.051 \mathrm{df}=1, p=.822$ ]. The resulting equation from the regression was used to calculate the probability of different variables on whether respondents support the closed fishing season or not and is shown in Fig. 5. The age of respondents and the number of years in the community have a common pattern as shown in Fig. 5A and 5B, which shows a higher tendency for younger respondents to support the fishing season policy with a range from 0.5 to 0.9 probability, while older respondents almost invariably support the closed fishing season policy at 0.7 to 0.9 probability. On the other hand, those with smaller household sizes have a higher tendency not to support the closed fishing season compared to those who were very dependent on the fisheries, like 6-9 household sizes and greater than nine household sizes (Fig. 5C). In addition, those with better education, like high school graduates and college graduates, have better support for the closed fishing season (Fig. 5D). Also, those who sell all their fish catch have higher support for the closed fishing season than those who sell less (Fig. 5E). Moreover, those who own a boat and have received previous extension services are supportive of the closed fishing season, as well as those who did not come from a fisher family background (Fig. 5F).

\subsection{Daily activities of women (FGD)}

Based on the data gathered during the focus groups on women's daily activities within their households, these are domestic in nature, e.g., cooking, gathering water, house cleaning, and doing laundry. The fisheries-related activities included repairing damaged nets that generated an income of Php 700-Php 1,000.00 (U\$14.44-20.62 U\$) per week, distributing their husband's catch to "suki" or favored buyers, which generated Php 800 to Php 3,500 (U\$16.50-72.50 U\$) per week. In addition, other activities such as drying fish, selling the product, and trading generated Php 700.00- Php 5,000.00 per week (U\$14.44$103.11 \mathrm{U} \$$ ). For non-fishing-related activities, women reported engaging in farming vegetables, and banana and coconut which they harvested every week for an extra income of approximately Php 70.00Php 500.00 (U\$1.44-10.31 U\$) per week.

\subsection{Challenges faced by women in the fisheries (FGD)}

The respondents were then asked to reveal problems they had faced in the Davao Gulf. The responses included an inadequate source of income, sea wall construction, which displaced the fishers' landing sites, and the low selling price of gleaned seashells and seaweed. Other problems included boat engines that need repairs or replacements, especially after encountering big waves from October to March during the northeast monsoon. Women respondents have expressed their primary needs as financial seed capital for fishing expenses or the replacement of worn-out fishing gear like nets, nylons, and hooks.

Most of the respondents suggested solutions to address these commonly encountered problems. Leading suggestions included developing facilities and infrastructure, such as creating a cold storage area and establishing community vessel landing centers. They also emphasized needing training 
programs that could help women diversify their livelihoods, such as cooking classes, dressmaking, baking, handicrafts, raising pigs and goats, small businesses, and fish processing.

\subsection{Discussion}

\subsection{Women's daily activities}

This study has shown that the role and participation of women in the small-scale fisheries in Davao Gulf can be divided into three phases, pre-fishing, post-fishing, and other activities related to processing. Prefishing activities include mending nets and equipment maintenance that both husband and wife can handle. Women also prepared food and other fishing accessory materials for their husbands' fishing activities, including hooks, baits, radio, and lights. The post-fishing activities include collecting and sorting fish, delivering fish, marketing fish and other fisheries resources, e.g., clams, shells, or seaweeds, and gleaning. Other post-fishing activities are preparing food again when their husbands return from a fishing trip, awaiting them at the port, and helping them to carry their fish catch and gears. In terms of processing activities, this included salting and drying of fish, farming, attending community meetings buying of fuel for the next fishing trip, hooks, nylons, and silk cloth.

Most of the women respondents from our study sites were also highly engaged in gleaning. For instance, those from Governor Generoso gleaned for family consumption rather than selling in the market compared to the women respondents in Honda bay, Palawan (Siar, 2003). If they sell their gleaned shellfish products, the respondents emphasized the importance of providing a fair price for their consumers. To the women, a product has a higher value only if this was sold at a reasonable price to the consumer, and the vendor can still profit. The price was considered fair if this was not influenced by the availability or volume of other fishery products in the market. Indeed in the literature, women were thought to emphasize group welfare rather than their self-interest, which makes it very interesting that even in market conditions, they seem to be consciously aware of this matter (Anthony and Horne, 2003). Women were thought to be less selfish and more socially orientated than men (Eckel and Grossman, 1998).

The women also played a predominant role in fish processing and marketing of fish products and other marine resources. Some of the processed finfish species for drying include rabbitfish, goatfish, parrotfish, roundscad, yellowfin tuna, swordfish, sardine, common squid, as well as, seaweeds (Mahmud et al., 2018; Mutia et al., 2020). Drying of finfish species and invertebrates are forms of food preservation to increase their shelf life, combat food spoilage, increase their value and provide variation in diet (Amit et al., 2017). Women also prepared or sold cooked and raw fish pastes that are used as food additives during cooking of meat or vegetables or for eating raw fruits or even vegetables (Bashir et al., 2017). They also sell their dried fish, squid, or seaweeds and the fresh fish catch to their neighbors, financiers, traders, or directly in the public market.

\subsection{Access to financial services}


The women respondents in this study have higher access to credit than men. Perhaps this is because the microcredit institutions have more confidence in them to repay their loans compared to the men. This is somewhat related also to female students who were more likely to repay their loans than male students who have student loans, with $58 \%$ of them holding student loan debt (AAUW, 2017). Women took the risk of financing their college education through debts to avoid having lower pay when they are already employed and without a college degree; they also fared better once they graduate (Cotter et al., 2004; Dwyer et al., 2013; England, 2010). They are also thought to be more cooperative than men, even in studies regarding microcredit borrowing (Anthony and Horne, 2003). Other studies have shown that women have higher integrity to pay back their loans compared to men; they are more trustworthy than men, and that they are more likely to repay their loans irrespective of any control mechanisms (Shahriar et al., 2019). A global analysis on micro-credit financial institutions has shown that women are also more likely to pay their debts than men are (D'Espallier et al., 2011). In the Philippines, women seem to have more practice in handling finances as they are usually the family member managing their household's finances. They are known to take the initiative to borrow money for their family's food security, school tuition fees or for emergency needs. The most common financial credit available for the respondents were from both formal and informal institutions. Formal lending institutions includes micro-credit corporations like ASA Philippines Foundation, CARD Incorporated Philippines, other rural banks. This was in contrast to the study of Siason (2001), where women respondents during that time have only access to informal sources of credit while men borrowed from formal financial institutions. Financial inclusion among rural coastal women should be mainstreamed and spearheaded by the government's DSWD (Department of Social Welfare and Development), DOLE (Department of Labor and Employment) as well as Landbank to provide a seed capital for their entrepreneurial activities and reduce poverty rates (Bank, 2018; Bhatia and Singh, 2019).

\subsection{Access to extension services and community organizations}

Regardless of how busy women were, they were still active members in their community organizations, especially in fishing cooperatives where they attend meetings. Fisher's spouses often represent their husbands during fishers or farmers organization meetings even though the membership remains traditionally male-dominated (Siason, 2001). In this study, the respondents mentioned that they were also active participants in various training activities that included livelihood training from fish deboning, mangrove planting, agri-fishermen training, seaweed planting, livestock raising and even other capacitybuilding activities like baking, cosmetics, welding, plumbing etc. The women have stressed the importance of the said activities and the need to increase the number of trainings and assistance to facilitate their participation (ADB, 2019). Such activities as raising their awareness of their human rights and gender equality and violence against women and children and community-based livelihood activities can serve as initial steps towards sustainable livelihood; as a well-informed woman becomes an independent and productive member of the community (PILIPINA, 2015). In a study in Bangladesh, women were encouraged to be involved in construction, maintenance, and tree plantation activities through labor contracting societies and participation in local governance and the management of union 
councils (ADB, 2010). Their participation helped them challenge gender stereotypes and other unfair social norms as women can also contribute to development as much as men can do (ADB, 2019). Extension services to women helped to ease gender differences as women are sometimes considered more vulnerable to exploitation and more likely to suffer in poverty. In rural extension activities, women are given particular attention because they are systematically marginalized and undervalued in conventional agricultural and economic analyses and policies. At the same time, men's contribution remains the central, often the sole, focus of attention (Jiggins et al., 1997). It is typically assumed in rural areas that men are fishers in coastal fishing communities and women only play a "supportive role" as either fishers' wives (Siason, 2001). These assumptions are an impediment to women's participation in the wider local economy and one reason why gendered developments are being advocated in support for social protection of women and children (ADB, 2019; PILIPINA, 2015). Yet in spite of the mainstreaming of support by the DSWD (Department of Social Welfare and Development), during the study we found that there were no active women organizations in the fisheries visited in this study. Perhaps this gap, can be addressed in latter projects by the DSWD and the BFAR (Bureau of Fisheries and Aquatic Resources) as it has the potential to help uplift rural women to become more productive as they face better opportunities.

\subsection{Fish catch, revenue, and marketing}

Apart from enthusiastically expressing their sentiments concerning their husband's fish catch success, the respondents also look forward to selling the catch for revenue to have cash to cover for their basic needs. Unfortunately, the volume of fish catch is not the same every day or consistent every month (Macusi et al., 2021). The catch can be affected by several factors, from bad weather, fishing experience, seasonal abundance, and even due to climate change(Macusi et al., 2015; Monnier et al., 2020). Economic motivation is high among fishers, and their dependence on the fisheries makes them unwilling to move away from their livelihood to find other opportunities outside the fisheries (Macusi et al., 2017; Muallil et al., 2011). Moreover, fishers who do not own their boats and part of a crew, are left with lower profit. The profit-sharing scheme removes a chunk from their income which makes it difficult for their wives to budget their money for their daily expenses. It can turn for the worse during the months of October to March in Davao Gulf as fishers often encounter bigger waves in their fishing grounds during this time. Their catches are at a minimum and the lower revenue forces them to seek credit or loans rather than suffer hunger (Barbier, 2015; Macusi et al., 2021).

In addition, the respondents were also aware of the implementation of the closed and open fishing season. However, since they are largely unaffected by the closed fishing season policy, they maintained their level of fishing regardless of the closure. To most participants in the study, the closed fishing season somewhat raised their awareness of sustainable fishing, which influenced them to adopt good fishing practices. However, training on the side of the government and NGOs dedicated to increasing the level of knowledge and awareness of fishers and their wives to use sustainable fishing practices are still inadequate in the visited places. These trainings are good ways to enlist the whole community's participation towards sustainable fishing practices (Digal and Placencia, 2017). A related study happened 
in San Pablo City, Laguna, which was crucial to express operative management and conservation strategy when identifying the resources existing in the local community. The government actually lacked the workforce to enforce existing environment-related policies because it did not train community members to help in resource management and conservation (Anastacio et al., 2018). Moreover, women's perspectives in most of the study areas, their opinions on conservation strategies are not currently acknowledged or heard in community organizational meetings due to apparent lack of inclusiveness.

\subsection{Conclusions}

Women remain supportive of their husbands' fishing activities through their participation in the prefishing, post-fishing and marketing activities. They are also actively engaged in gleaning for food security concerns and are very willing to get into debt through microfinance institutions to address food security issues, education of their children and other emergency needs. However, most of the respondents do not belong to any fishing organizations or advocacy groups for marine conservation or for women's issues, which contrasts the men in the community who were vocal and engaging with regards to their right to fish and access to resources or extension services. Women have openly requested for better livelihood projects in their communities which could help them in their entrepreneurship drives and financial access. Their participation in representing their husbands during community meetings and in community organizations provide them an avenue to voice their concerns regarding fisheries and marine conservation, which is essential to sustain their livelihoods in the future.

Their enthusiasm to attend meetings for their husbands show their openness and commitment to help formulate and make better decisions for their community's future. Nevertheless, training these women to form their community care groups and advocacies will help facilitate other valuable helps coming from interested organizations. Thus, training programs in the fisheries such as food processing, technical landbased jobs like welding, plumbing, cosmetics, and livestock raising should include women who are open to these jobs. Above all, inclusiveness in community decision-making to address community issues and problems should be practiced. Women's perspectives will remain valuable not only as an input for gender equality but also for better protecting marine and fisheries resources.

\section{Declarations}

\section{Funding Statement}

This research project was funded by the Philippine Council for Agriculture, Aquatic and Natural Resources Research and Development of the Department of Science and Technology (PCAARRD) through the project entitled: "Fisheries catch assessment using GPS trackers and effort survey of municipal and commercial fishers in Mindanao". Additional funds came from SEARCA (Southeast Asian Regional Center for Graduate Study and Research in Agriculture) through the project entitled: "Biological and socioeconomic impacts of the closure fishing ban in Davao Gulf and the Zamboanga Peninsula: relevance of effort distribution and role of governance". 


\section{Acknowledgment}

We would like to acknowledge the help of fishers, the municipal agricultural officers and the various barangay captains from Governor Generoso, Lupon, Bunawan and Lasang, Sta. Maria, Don Marcelino and Malita for taking part in this study and opening their doors whenever we go back for surveys, additional data and for information dissemination in their areas. Special thanks is also extended to Michael Jeriel Bersaldo for the assistance provided in Davao Occidental study areas.

\section{Conflict of Interest}

The authors declare no conflict of interest

\section{References}

1. AAUW. 2017. Deeper in debt, women and student loans. 60. Washington DC: American Association of University Women.

2. ADB. 2010. Rural Infrastructure Improvement Project II. Gender Equality Results: Case Studies Bangladesh. 11-18. Philippines: Asian Development Bank, Mandaluyong City.

3. ADB. 2019. Development without women is not development: Why gender matters to Asian Development Bank. 50. Mandaluyong City: Asian Development Bank.

4. Amit, S. K., M. M. Uddin, R. Rahman, S. M. R. Islam, and M. S. Khan. 2017. A review on mechanisms and commercial aspects of food preservation and processing. Agriculture \& Food Security 6: 51.

5. Anastacio, N. J. C., M. M. Paunlagui, and K. S. Janiya. 2018. Gender Perspectives in CommunityBased Natural Resource Utilization and Management in Pandin Lake, San Pablo City, Laguna, Philippines. Journal of Human Ecology 7: 61-74.

6. Anthony, D., and C. Horne. 2003. Gender and Cooperation: Explaining Loan Repayment in MicroCredit Groups. Social Psychology Quarterly 66: 293-302.

7. Arenas, M. C., and A. Lentisco. 2011. Mainstreaming gender in fisheries and aquaculture: A Stocktaking and Planning Excercise - Final Report. Rome, Italy: Food and Agriculture Organization.

8. Bank, W. 2018. Financial inclusion is a key enabler to reducing poverty and boosting prosperity. World Bank.

9. Barbier, E. B. 2015. Climate change impacts on rural poverty in low-elevation coastal zones. Estuarine, Coastal and Shelf Science 165: A1-A13.

10. Bashir, K. M. I., J.-S. Kim, J. H. An, J. H. Sohn, and J.-S. Choi. 2017. Natural Food Additives and Preservatives for Fish-Paste Products: A Review of the Past, Present, and Future States of Research. Journal of Food Quality 2017, 9675469. 
11. Bhatia, S., and S. Singh. 2019. Empowering Women Through Financial Inclusion: A Study of Urban Slum. VIKALPA: The Journal for Decision Makers 44: 182-197.

12. Biswas, N. 2017. Towards gender-equitable small-scale fisheries governance and development. Rome, Italy: Food and Agriculture Organization.

13. Bradford, K., and R. E. Katikiro. 2019. Fighting the tides: A review of gender and fisheries in Tanzania. Fisheries Research 216: 79-88.

14. Cliffe, P. T., and O. A. Akinrotimi. 2015. Role of Women in Fishery Activities in Some Coastal Communities of Rivers State, Nigeria. International Journal of Agricultural Research 10: $24-32$.

15. Cotter, D. A., J. M. Hermsen, and R. Vanneman. 2004. Gender inequality at work. New York: Russell Sage Foundation.

16. D’Espallier, B., I. Gue, and R. Mersland. 2011. Women and Repayment in Microfinance: A Global Analysis. World Development 39: 758-772.

17. Digal, L. N., and S. G. P. Placencia. 2017. Factors affecting the adoption of sustainable tuna fishing practices: The case of municipal fishers in Maasim, Sarangani Province, Region 12, Philippines. Marine Policy 77: 30-36.

18. Dolan, C. 2001. The "Good Wife": Struggles over Resources in the Kenyan Horticultural Sector. Journal of Development Studies 37: 39-70.

19. Dworkin, S. L. 2012. Sample size policy for qualitative studies using in-depth interviews. Archives of Sexual Behavior 41: 1319-1320.

20. Dwyer, R. E., R. Hodson, and L. McLoud. 2013. GENDER, DEBT, AND DROPPING OUT OF COLLEGE. Gend Soc 27: 30-55.

21. Eckel, C. C., and P. J. Grossman. 1998. Are Women Less Selfish Than Men? Evidence From Dictator Experiments. Economic Journal 108: 726-723.

22. England, P. 2010. The gender revolution. Uneven and stalled Gender \& Society 24: 149-166.

23. Ferrer, A. J. G., M. L. Perez, A. T. Roxas, and E. M. Avila. 2014. Expanding Roles of Men and Women in Aquatic Agricultural Systems in the Philippines. Asian Fisheries Science 27S: 185-194.

24. Fitriana, R., and N. Stacey. 2012. The role of women in the fishery sector of Pantar Island, Indonesia. Asian Fisheries Science 25: 159-175.

25. Fortnam, M., K. Brown, T. Chaigneau, B. Cronac, T. M. Daw, D. Gonçalves, C. Hicks, M. Revmatas, C. Sandbrook, and B. Schulte-Herbruggen. 2019. 2019. The gendered nature of ecosystem services. Ecological Economics 159, 312-325.

26. Ingabire, C., P. M. Mshenga, M. Amacker, J. K. Langat, C. Bigler, and E. A. Birachi. 2018. Agricultural transformation in Rwanda: Can Gendered Market Participation Explain the Persistence of Subsistence Farming? Gender and Women's Studies 2: 1-18.

27. Jiggins, J., R. K. Samanta, and J. E. Olawoye. 1997. Improving women farmers' access to extension services. In Improving agricultural extension. A reference manual, eds. B. E. Swanson, R. P. Bentz, and A. J. Sofranko, Italy: Food and Agriculture Organization Rome. 
28. Katikiro, R. E., E. D. Macusi, and K. H. M. A. Deepananda. 2015. Challenges facing local communities in Tanzania in realising locally-managed marine areas. Marine Policy 51: 220-229.

29. Kim, Y.-R., and J.-M. Choi. 2020. Effects of Income Inequality on Satisfaction in Life Perceived by Female Fishermen - Focused on the Mediating Effect of Depression. Journal of Marine and Island Cultures 9: 167-180.

30. Lentisco, A., and E. Alonso. 2012. On Gender Mainstreaming Strategies and Tools in Fisheries Development Projects: RFLP Gender Strategy and Lessons from the Asia-Pacific Region. Asian Fisheries Science $25(\mathrm{~S}):$ 105-117.

31. Lentisco, A., and R. Lee. 2014. Beyond Fish Processors and Caregivers: Women as Primary, Secondary and Tertiary Fish Users Asian Fisheries Science (2014): 33-42 27S, 33-42.

32. Lentisco, A., and R. U. Lee. 2015. A Review of Women's Access to Fish in Small-Scale Fisheries. Rome, Italy: Food and Agriculture Organization (FAO).

33. Macusi, E. D. 2015. Fish Aggregating Devices (FADs) and the role of socioeconomic factors in driving spatial effort allocation of fishers. Los Banos, Laguna: Southeast Asian Regional Center for Graduate Study and Research in Agriculture (SEARCA).

34. Macusi, E. D., R. P. Babaran, and P. A. M. van Zwieten. 2015. Strategies and tactics of tuna fishers in the payao (anchored FAD) fishery from general Santos city, Philippines. Marine Policy 62: 63-73.

35. Macusi, E. D., R. P. Babaran, and P. A. M. van Zwieten. 2016. Socioeconomic and fishing operation characteristics of artisanal and commercial Fish Aggregating Devices (FAD) fishers from Southern Philippines 2nd International Conference on Fisheries and Aquatic Sciences. University of the Philippines Visayas, Ilo-ilo City, Philippines.

36. Macusi, E. D., R. E. Katikiro, and R. P. Babaran. 2017. The influence of economic factors in the change of fishing strategies of anchored FAD fishers in the face of declining catch, General Santos City, Philippines. Marine Policy 78: 98-106.

37. Macusi, E. D., A. K. O. Liguez, E. S. Macusi, and L. N. Digal. 2021. Factors influencing catch and support for the implementation of the closed fishing season in Davao Gulf, Philippines. Marine Policy, 104578.

38. Macusi, E. D., E. S. Macusi, L. A. Jimenez, and J. P. Catam-isan. 2020. Climate change vulnerability and perceived impacts on small-scale fisheries in eastern Mindanao. Ocean \& Coastal Management 189: 105143.

39. Mahmud, A., B. Abraha, M. Samuel, H. Mohammedidris, W. Abraham, and E. Mahmud. 2018. Fish preservation: a multi-dimensional approach. Food Processing and Technology 6: 303-310.

40. Mason, M. 2010. Sample size and saturation in PhD studies using qualitative interviews. Forum Qual. Soc. Res. 11, [Article No. 8].

41. Monnier, L., D. Gascuel, J. J. Alava, M. J. Barragán, N. Gaibor, F. A. Hollander, P. Kanstinger, S. Niedermueller, J. Ramírez, and W. W. L. Cheung. 2020. Small-scale fisheries in a warming ocean: exploring adaptation to climate change. Scientific report: WWF Germany. 
42. Muallil, R. N., R. C. Geronimo, D. Cleland, R. B. Cabral, M. V. Doctor, A. Cruz-Trinidad, and P. M. Aliño. 2011. Willingness to exit the artisanal fishery as a response to scenarios of declining catch or increasing monetary incentives. Fisheries Research 111: 74-81.

43. Mutia, M. T. M., M. L. Magistrado, M. J. L. Fermaran, and M. C. Muyot. 2020. Gender Participation in the Fisheries Sector of Lake Taal, Philippines. The Philippine Journal of Fisheries 27: 157-182.

44. Parks, M. H., M. E. Christie, and I. Bagares. 2014. Gender and conservation agriculture: constraints and opportunities in the Philippines. GeoJournal 80: 61-77.

45. Pavo, R. R., and L. N. Digal. 2017. Women's Space in the Fish Port Tambler Complex and the ValueChain Nodes of the Fishing Industry in General Santos City,Philippines. Asian Fisheries Science 30S: 33-58.

46. PILIPINA. 2015. Philippines: Strengthened Gender Impacts of Social Protection, Social Protection Support Project Department of Social Welfare and Development, Quezon City, Philippines, p. 34.

47. Rola, A. C., T. A. Narvaez, M. R. A. Naguit, D. D. Elazegui, B. B. C. Brillo, M. M. Paunlagui, H. C. Jalotjot, and C. P. Cervantes. 2018. Impact of the closed fishing season policy for sardines in Zamboanga Peninsula, Philippines. Marine Policy 87: 40-50.

48. Shahriar, A. Z. M., L. A. Unda, and Q. Alam. 2019. Gender Differences in the Repayment of Microcredit: The Mediating Role of Trustworthiness. Journal of Banking and Finance.

49. Siar, S. 2003. Knowledge, Gender, and Resources in Small-Scale Fishing: The Case of Honda Bay. Palawan, Philippines. Environmental Management 31: 569-580.

50. Siason, I. 2001. Women in fisheries in the Philippines, in: Williams, M.J., Nandeesha, M.C., Corral, V.P., Tech E., P.S., C. (Eds.), International Symposium on Women in Asian Fisheries Fifth Asian Fisheries Forum, Asian Fisheries Society. ICLARM-The World Fish Center, Chiang Mai, Thailand, pp. 69-77.

51. Villanueva, J. A. 2018. Assessment of Commercially Important Small Pelagic Fishes in Davao Gulf CY 2004-2013. The Philippine Journal of Fisheries 25: 163-182.

52. Weeratunge, N., K. A. Snyder, and C. Poh Sze. 2010. Gleaner, fisher, trader, processor: understanding gendered employment in fisheries and aquaculture. Fish Fish 11: 405-420.

\section{Figures}




\section{Study sites}

Davao City

Population: 1,632,991

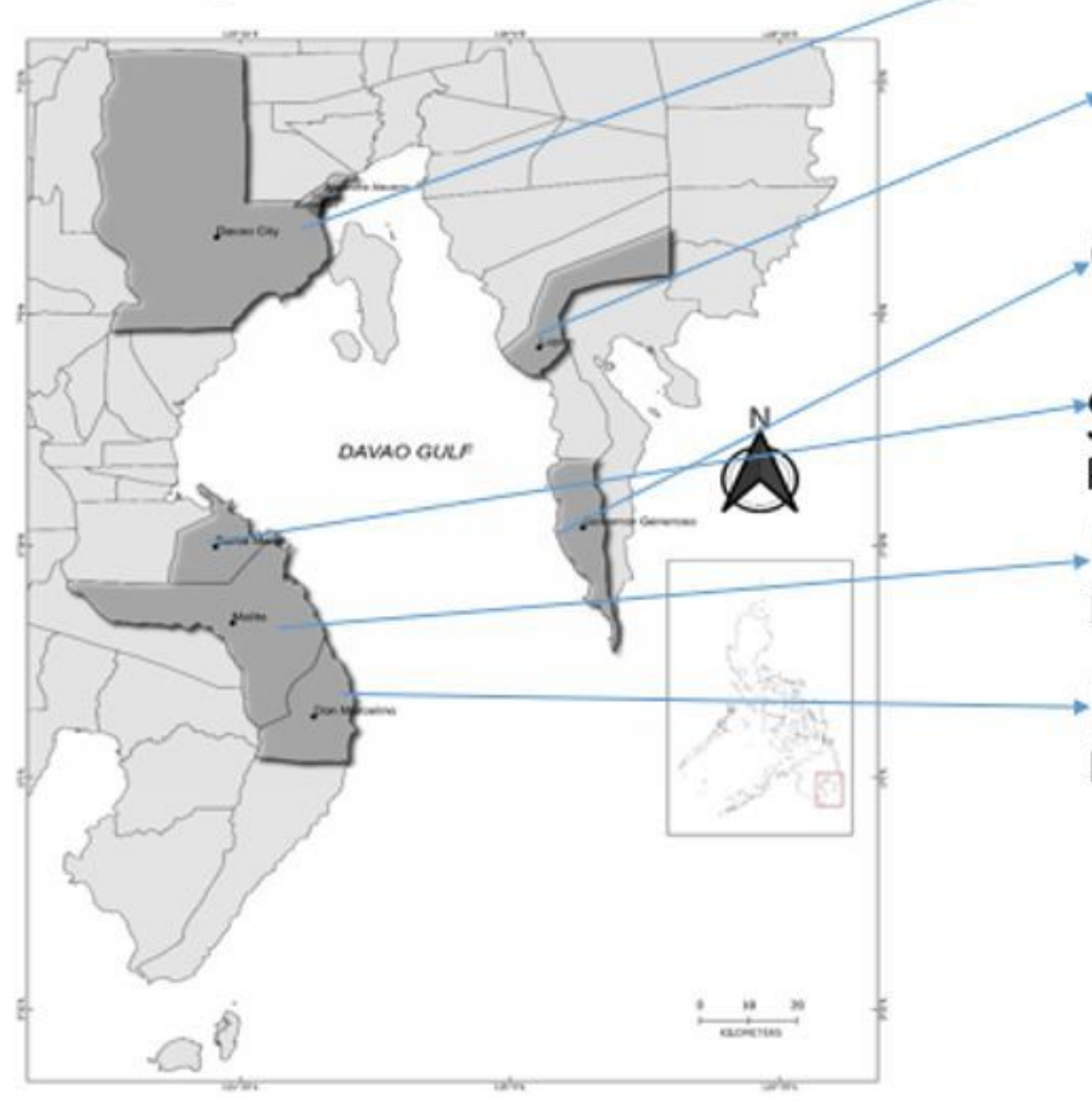

Lupon

Population: 65,785

Governor Generoso

Population: 55,109

Sta. Maria

Population: 53,671

Malita

Population: 117,746

Don Marcelino

Population: 44,554

Figure 1

Map of the Davao Gulf region in Mindanao, Philippines and the location of the 6 study sites surveyed (Source of Philippine's map: Google map 2020) 

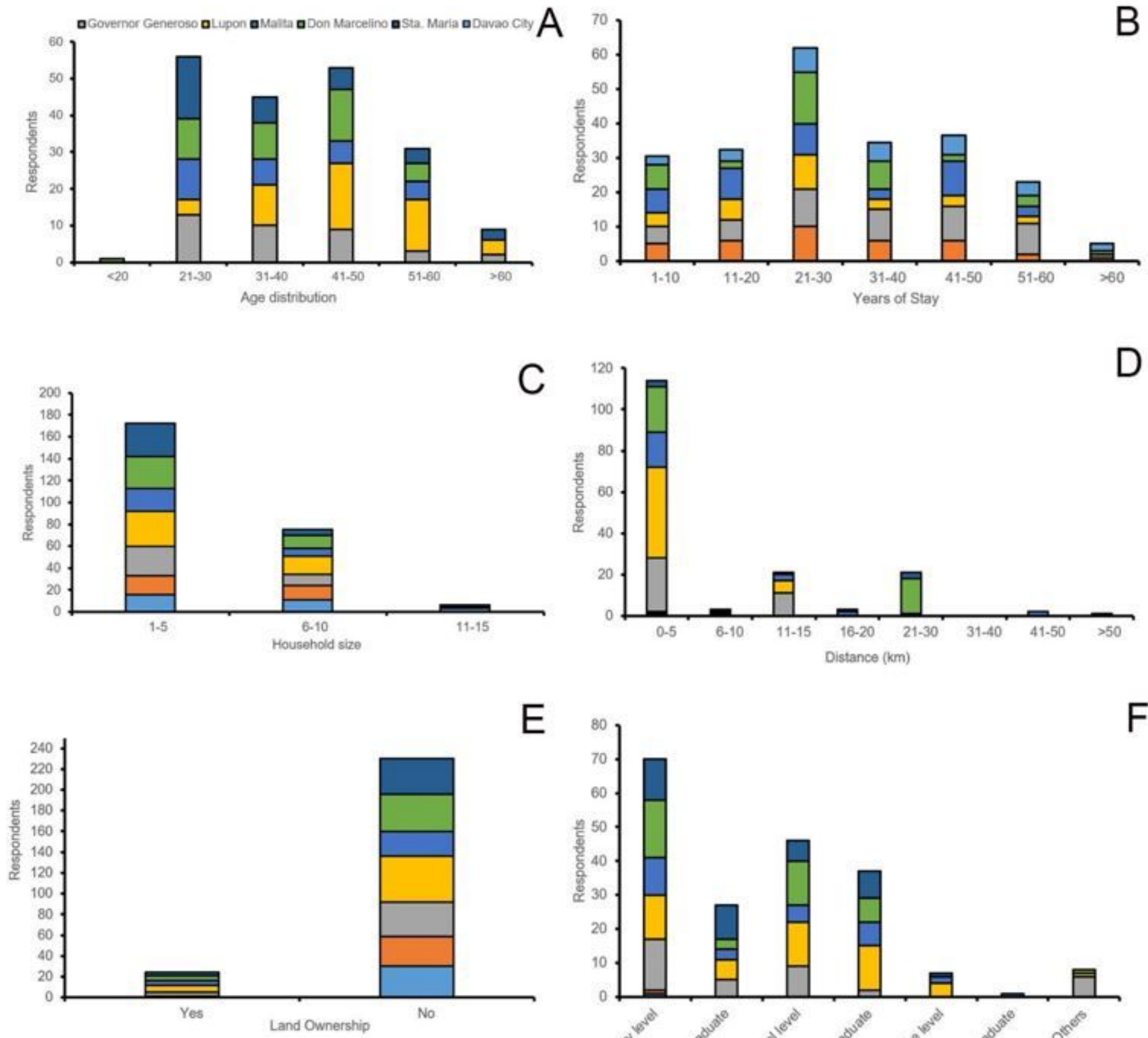

E

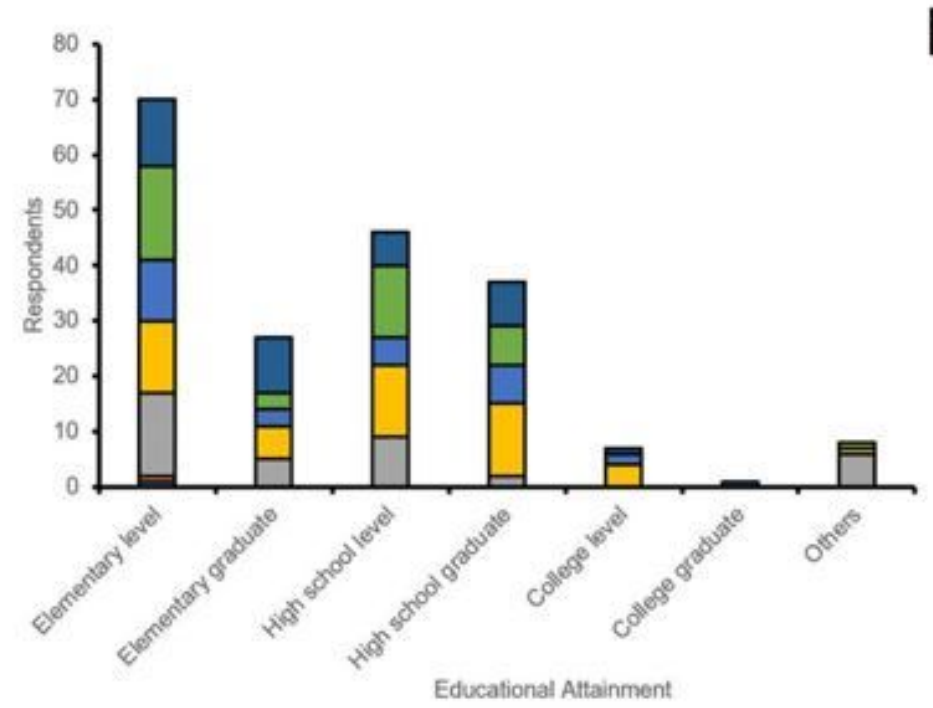

Figure 2

Socioeconomic profile of respondents, their age distribution (A), years in the community (B), household size (C), distance from shore to house (D), land ownership (E), and educational attainment $(F)$ in the various study sites $(\mathrm{N}=255)$. 
A

B
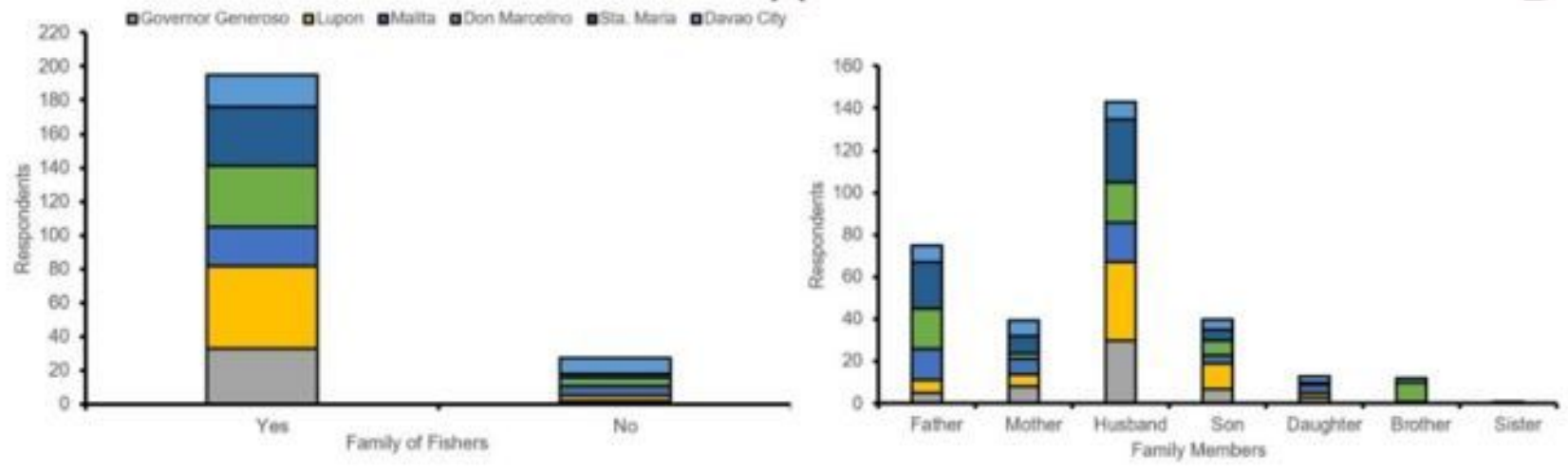

C
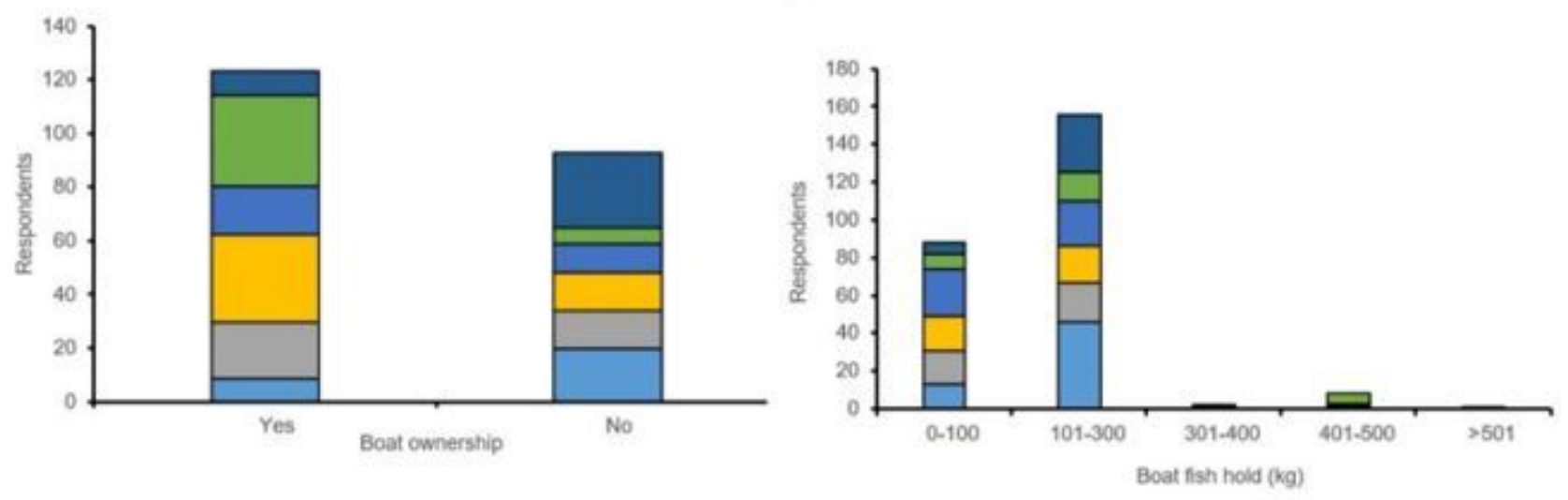

E

$\mathrm{F}$
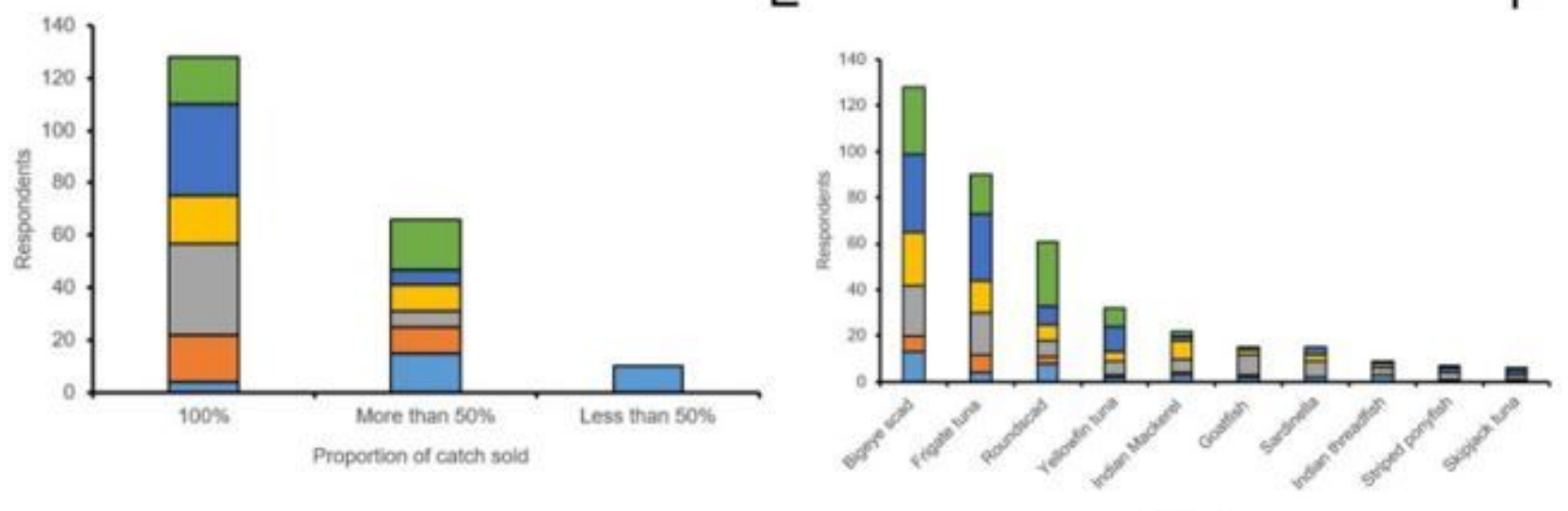

Fish Species

\section{Figure 3}

Participation of respondents in the fisheries: they belong to a family of fishers (A), family members are actively engaged in the fisheries (B), they own fishing boats (C) with different fish hold capacities (D), and fishers usually sell their catch in different proportions depending on their needs for food and income (E), and commonly caught species $(\mathrm{F})$ in the study sites $(\mathrm{N}=255)$. 
A

B
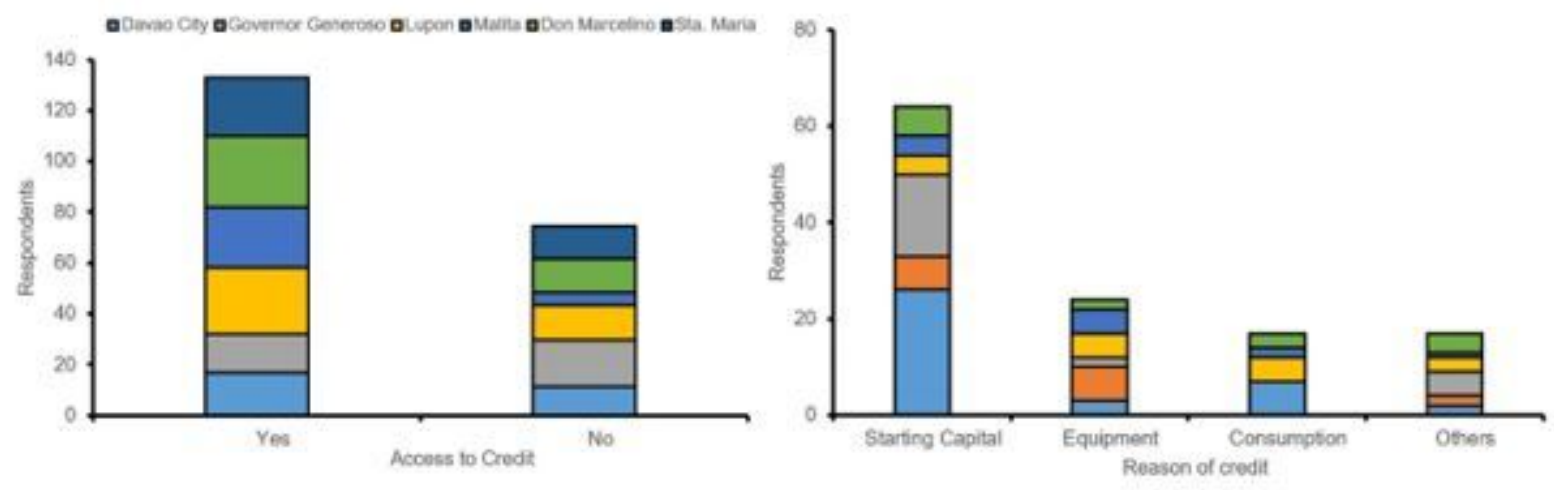

C

D
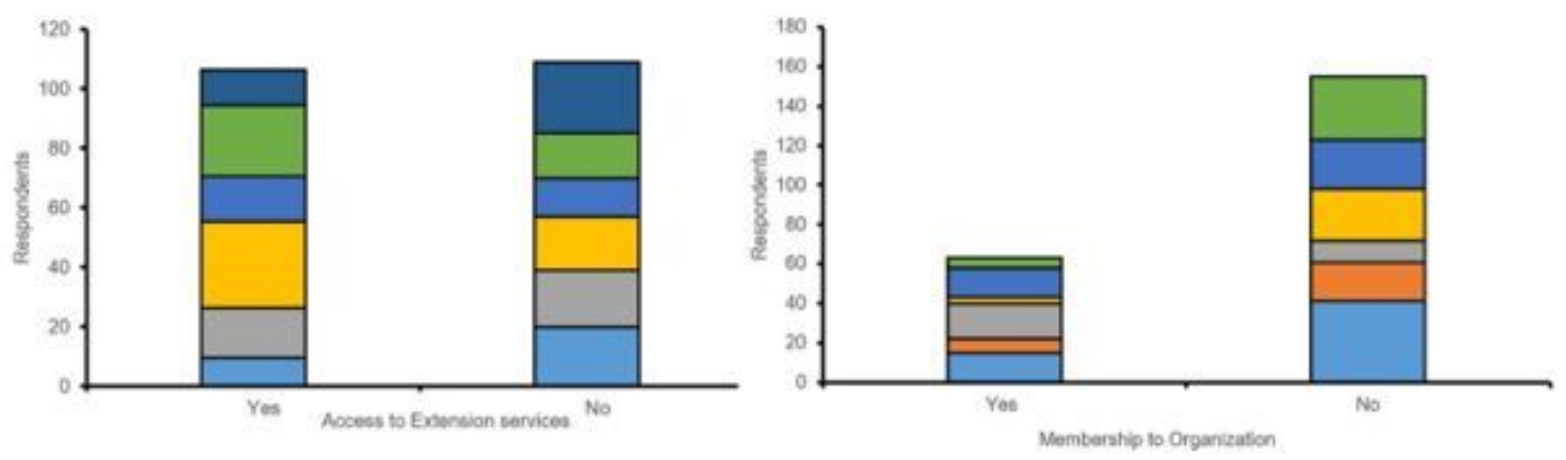

$\mathrm{E}$

$\mathrm{F}$
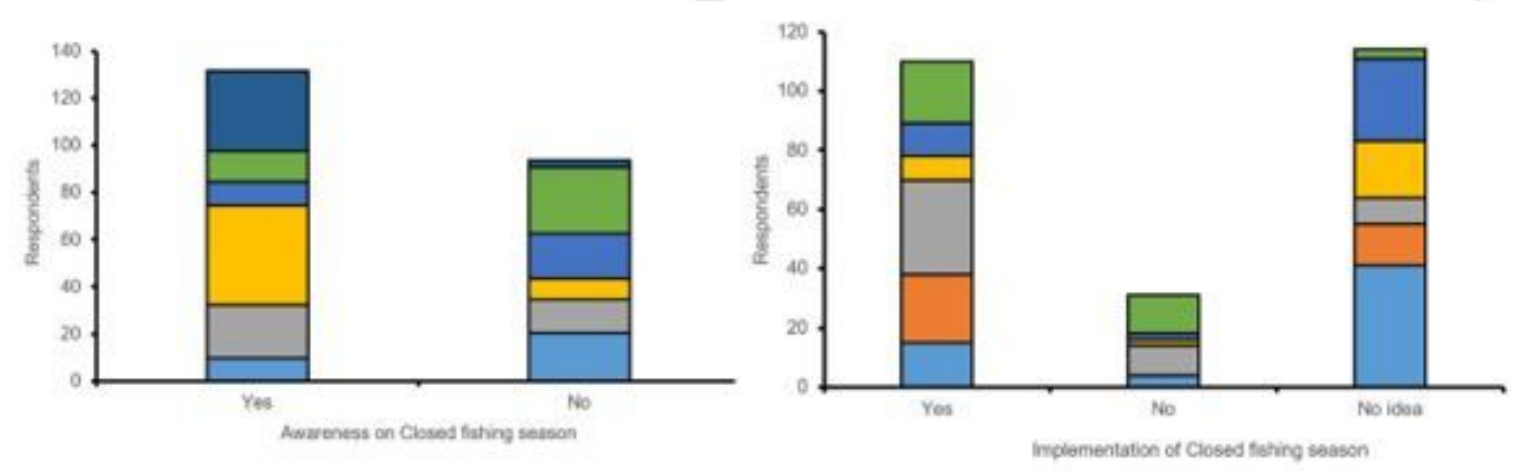

Figure 4

Access of women respondents to credits (A), their reasons for credit access (B) and extension services (C) and belonging to fishing organization (D), their awareness of closed fishing season in their community (E) and support for the implementation of the closed fishing season (F) of respondents in the study site $(\mathrm{N}=255)$. 
A

B
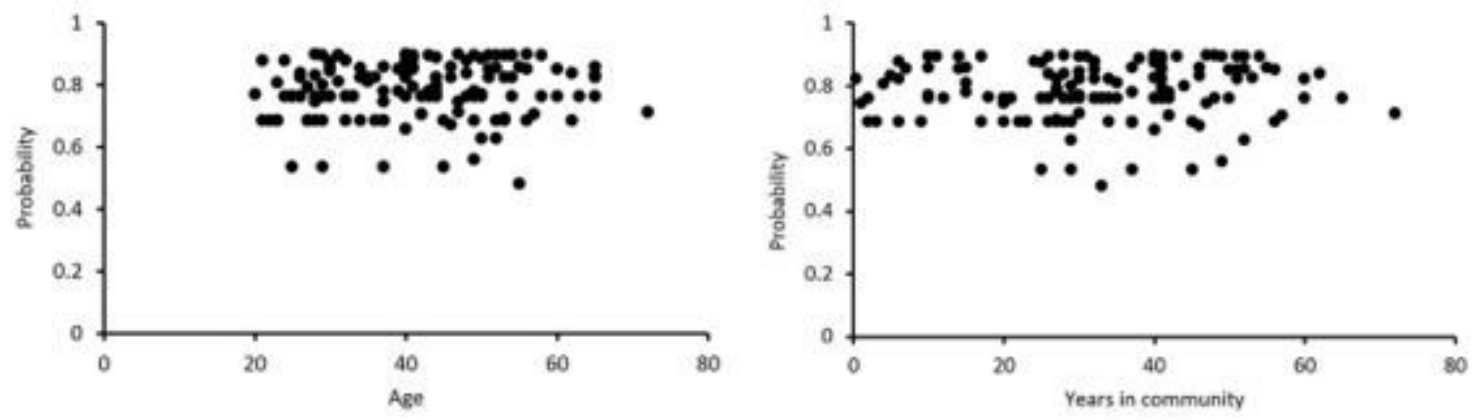

C
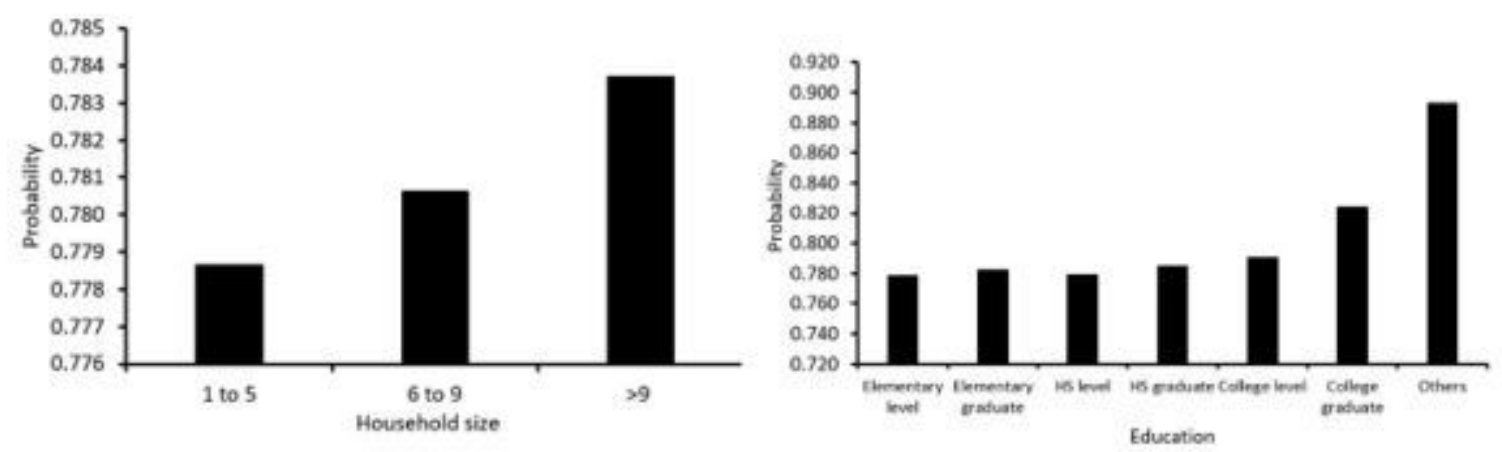

$E$

$\mathrm{F}$
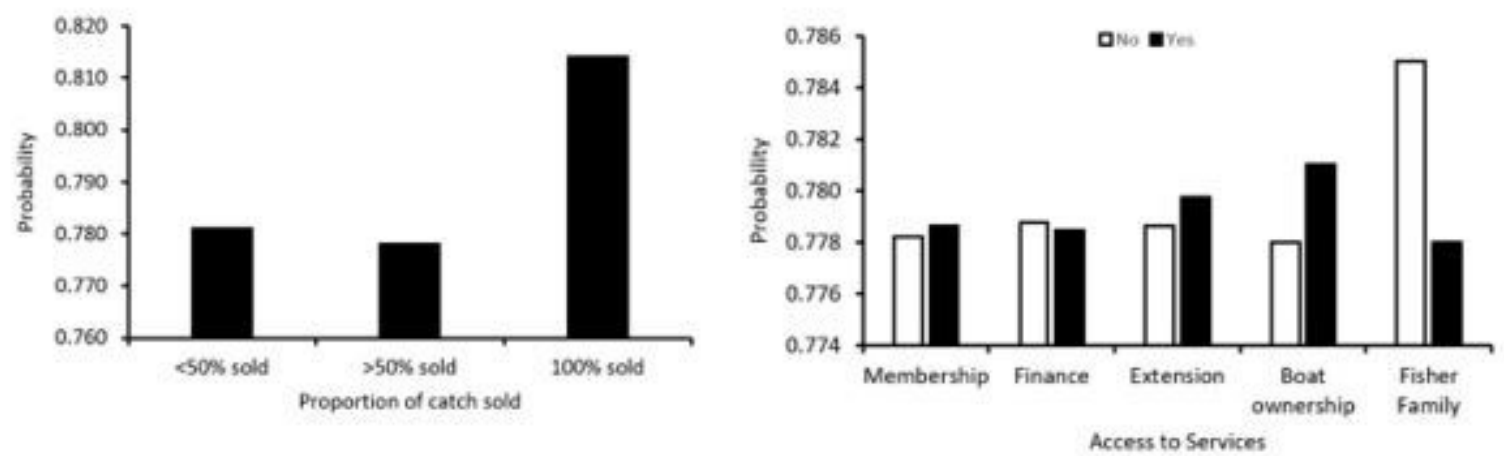

Figure 5

Probability of support for closed fishing season depending on age (A), years in the community (B), household size (C), levels of education (D), proportion of catch sold by fisher (E) and access of women respondents to financial credits, membership to community organizations, awareness of the closed fishing season, extension services received, belonging to a fisher family $(F)$ in the various study sites $(\mathrm{N}=255)$.

\section{Supplementary Files}


This is a list of supplementary files associated with this preprint. Click to download.

- Abstractwomensupportforclosedfishingseason.docx

- CoverLettertotheEditorwomenclosedfishingseason.docx 